\title{
Predicting habitat preferences for Anthometrina adriani (Echinodermata) on the East Antarctic continental shelf
}

\author{
L. G. Hemery ${ }^{1, *}$, B. Galton-Fenzi ${ }^{2}$, N. Améziane ${ }^{1}$, M. J. Riddle ${ }^{3}$, S. R. Rintoul ${ }^{2,4}$, \\ R. J. Beaman ${ }^{5}$, A. L. Post ${ }^{6}$, M. Eléaume ${ }^{1}$ \\ ${ }^{1}$ Muséum national d'Histoire naturelle, UMR7208 BOREA, 75005 Paris, France \\ ${ }^{2}$ Antarctic Climate and Ecosystems Cooperative Research Centre, University of Tasmania, Hobart, Tasmania 7000, Australia \\ ${ }^{3}$ Australian Antarctic Division, Kingston, Tasmania 7050, Australia \\ ${ }^{4}$ CSIRO Marine and Atmospheric Research, Hobart, Tasmania 7000, Australia \\ ${ }^{5}$ School of Earth and Environmental Sciences, James Cook University, Cairns, Queensland 4870, Australia \\ ${ }^{6}$ Geoscience Australia, Canberra, ACT 2601, Australia
}

\begin{abstract}
The comatulid crinoid Anthometrina adriani is well represented among the suspension-feeding megaepibenthos from the continental shelf of the Dumont D'Urville Sea, Antarctica. Nearly 500 specimens were sampled during the Collaborative East Antarctic Marine Census expedition onboard the RV 'Aurora Australis' (December 2007 to January 2008), from 50 of the 87 stations over a $400 \mathrm{~km}^{2}$ area. Abiotic environmental factors were measured and an ocean circulation model was used to generate near-bottom parameters. The ecological niche of A. adriani was described by using ecological-niche factor analysis and Mahalanobis distances factor analysis. An environmental suitability map (ESM) was developed to map the optimal habitat. A. adriani prefers moderately deep and relatively cold waters with moderate current velocity, and a substrate with low gravel content and biogenic carbonate. The ESM shows 4 optimal regions: the eastern side of the George V Basin, the eastern side of the Adélie Basin, the southern part of the Adélie Bank, and the coastal area between the Astrolabe and Mertz glaciers. The ecological niche for A. adriani appears very narrow, but the species is widely distributed across the Antarctic shelf. It suggests that local changes in limiting factors have a strong local effect on the distribution of this species and that a total eradication of this species from the shelf would need an Antarctic-wide and synchronic change in these essential parameters. Modeling modifications in environmental conditions under different climate change scenarios could help predict the effect of such changes on the distribution of this selective species.
\end{abstract}

KEY WORDS: Ecological niche - Optimal habitat - Antarctica $\cdot$ Crinoid $\cdot$ Anthometrina adriani Ocean circulation model

\section{INTRODUCTION}

Studying the ecological niche (sensu Hutchinson 1957) of marine organisms living on the Antarctic continental shelf is a necessary step towards a greater understanding of many aspects of Antarctic scientific and environmental issues, such as circumpolarity, species diversification and the potential effects of global warming and ocean acidification. Defining the physical characteristics of the niche allows us to model the distribution of a species and to make predictions of how this may 
change with different environmental conditions, for example under a range of climate change scenarios.

Many species on the Antarctic shelf appear to be circumpolar in distribution. This is thought to be due in part to some broad-scale ecological conditions being similar around most parts of the continent, e.g. low and relatively stable seawater temperatures, a short phase of primary production and low terrigenous input (Bullivant 1959, Clarke 1996). The circumpolar coastal current transports food particles and supports the dispersal of juveniles (Underwood \& Fairweather 1989, Raguá-Gil et al. 2004). However, species distributions at a finer scale are patchy, not because of barriers to larval transport but most probably because of local conditions influencing species' settlement, growth and reproduction (Raguá-Gil et al. 2004, Gutt 2006).

Global warming is likely to have several effects on benthic communities in the Southern Ocean, with considerable variation from place to place (Smale \& Barnes 2008). A warmer ocean could lead to changes in sea ice conditions, increased freshwater input and sedimentation. Enhanced uptake of carbon dioxide in the ocean could lead to acidification that would result in changes in ocean $\mathrm{CaCO}_{3}$ chemistry and possible shoaling of carbonate saturation horizons (Smale \& Barnes 2008), which could have serious consequences for animals with calcareous shells or calcified skeletons such as molluscs and echinoderms (O'Donnell et al. 2009). It is therefore of increasing importance to predict the behavior and distribution of keystone species (sensu Paine 1969) in response to various scenarios of future climate. However, predictive habitat distribution models can deal only with a limited number of environmental variables (Guisan \& Zimmermann 2000). For this reason, it is necessary to know which limiting factors could influence the distribution and abundance of the study organism at a given locality.

This study focuses on comatulid crinoids (Crinoidea: Echinodermata) because they are well represented among the fauna of the Antarctic shelf. They represent a characteristic component of the calcified megaepibenthos in Antarctica with about 40 species described from the Antarctic shelf (see Eléaume 2006 for a review). The most common and abundant are the antedonid species from the subfamily Heliometrinae: Promachocrinus kerguelensis Carpenter, 1888, Florometra mawsoni Clark, 1937 and Anthometrina adriani (Bell, 1908; note that the generic name, Anthometra Clark, 1915, is being changed to Anthometrina Eléaume, Hess and Messing, 2011, owing to its junior status relative to a more senior available name [the lepidopteran Anthometra Boisduval, 1840]) (Eléaume et al. 2011a). These species are thought to be circumpolar in distribution (see Eléaume 2006 for a review). Comatulids are suspension-feeders and rely on currents to feed, reproduce and disperse (Meyer 1973, Macurda \& Meyer 1974, Meyer \& Macurda 1980). Analysis of video imagery from the Antarctic shelf (M. Eléaume unpubl. data) revealed that some species (e.g. P. kerguelensis and F. mawsoni) form clusters whereas other species (e.g. A. adriani) are solitary. Underwater observations have shown that some of these species live close to the seabed, whereas others are found perching on other benthic organisms; some comatulid species are also able to swim actively.

Among crinoids, Anthometrina adriani is a good model organism for investigating niche preferences because analysis of its genetic diversity from samples collected all around the Antarctic continent (M. Eléaume \& L. G. Hemery unpubl. results) indicates that it is a single species found all around the Antarctic shelf, as opposed to Promachocrinus kerguelensis, which has a large genetic diversity in the whole Southern Ocean and seems to be a complex of cryptic species (Wilson et al. 2007, L. G. Hemery unpubl. data). Analysis of available video footage (M. Eléaume unpubl. data) suggests that $A$. adriani does not swim actively as does $P$. kerguelensis, even when disturbed by a remotely operated vehicle. This suggests that $A$. adriani is a quasi-sessile comatulid. Moreover, there is no evidence of brooding in $A$. adriani, which suggests it is a broadcaster (type I of Eléaume et al. 2003), as was also described for P. kerguelensis (McClintock \& Pearse 1987), in which both males and females emit their gametes into the water column and the lecithotrophic larvae experience a short pelagic stage before settlement (McClintock \& Pearse 1987, Holland 1991). This reproductive mode with a pelagic stage could be the most important means of dispersion for A. adriani.

The questions addressed in this study are: Where can Anthometrina adriani establish and what environmental factors influence this species' distribution? To answer these questions, we describe the available habitat, the ecological niche and optimal habitat of $A$. adriani on a limited but intensely sampled sector of the East Antarctic shelf, in the Dumont D'Urville Sea, using a combination of abiotic factors measured in situ and oceanographic data calculated from an ocean circulation model. 


\section{MATERIALS AND METHODS}

\section{Sampling area}

The present study is based on the material collected during the Collaborative East Antarctic Marine Census (CEAMARC) on the RV 'Aurora Australis', which took place in offshore Terre Adélie and George V Land from December 2007 to January 2008 (Fig. 1). Broad-scale geomorphic features of the study area are the George V Basin (1300 $\mathrm{m}$ at the deepest), the Adélie and Mertz banks (mean depths: $200 \mathrm{~m}$ and $\sim 250 \mathrm{~m}$, respectively) (Post et al. 2011) and the Adélie Basin, which reaches depths of $>1200 \mathrm{~m}$ (Beaman et al. 2011). At the time of the CEAMARC survey, icebergs calving from the Astrolabe and Mertz glaciers were relatively small $(<1 \mathrm{~km})$ with a reduced keel depth and therefore were less likely to ground, compared with those sourced from the Cook Ice Shelf that have keel depths of up to $\sim 500 \mathrm{~m}$ are able to easily ground on the shallow northern margins of the Mertz and Adélie banks (Dowdeswell \& Bamber 2007). However, in February 2010, the Mertz Glacier tongue broke off and a huge iceberg $(>90 \mathrm{~km})$ was produced and drifted between the Mertz Bank and the George V Basin to join the shelf break north of the French base Dumont D'Urville and could have scraped the bottom on its course (www.aad.gov.au/ default.asp? casid=37766).

An essential feature of the area are the polynyas, sustained by katabatic winds (Massom et al. 2001), that form in the area to the west of the Mertz Glacier ice tongue and in the lee of grounded icebergs and embayments along the coast. High salinity shelf water (HSSW) is formed within the polynyas by brine rejection during winter sea ice production (Bindoff et al. 2000). The activity of the polynyas is controlled by the onshore movement of relatively warm modified circumpolar deep water (MCDW) (Rintoul 1998). The interaction of HSSW and MCDW leads to the formation of water that spills over the Adélie Sill as Adélie Land bottom water.

The George V and Adélie basins are dominated by muddy, biogenic rich sediments, while the Adélie Bank, the northwestern margin of the Mertz Bank and the shelf edge are all dominated by sandy sediments with minor mud and gravel content (Post et al. 2011). At least 6 distinct benthic assemblages occur on the shelf as a function of depth and substratum type. The importance of substratum properties in structuring these benthic communities is particularly clear in the distribution of suspension- and deposit/ detritus-feeder dominated communities. Suspension feeders are abundant on rocky and sandy substratum, while detritus and deposit feeders dominate the muddy basin sediments (Post et al. 2011).

\section{Sampling methods}

Anthometrina adriani is very abundant over the study area and shows little genetic diversity within its whole distribution area, which suggests the absence of cryptic speciation (M. Eléaume \&

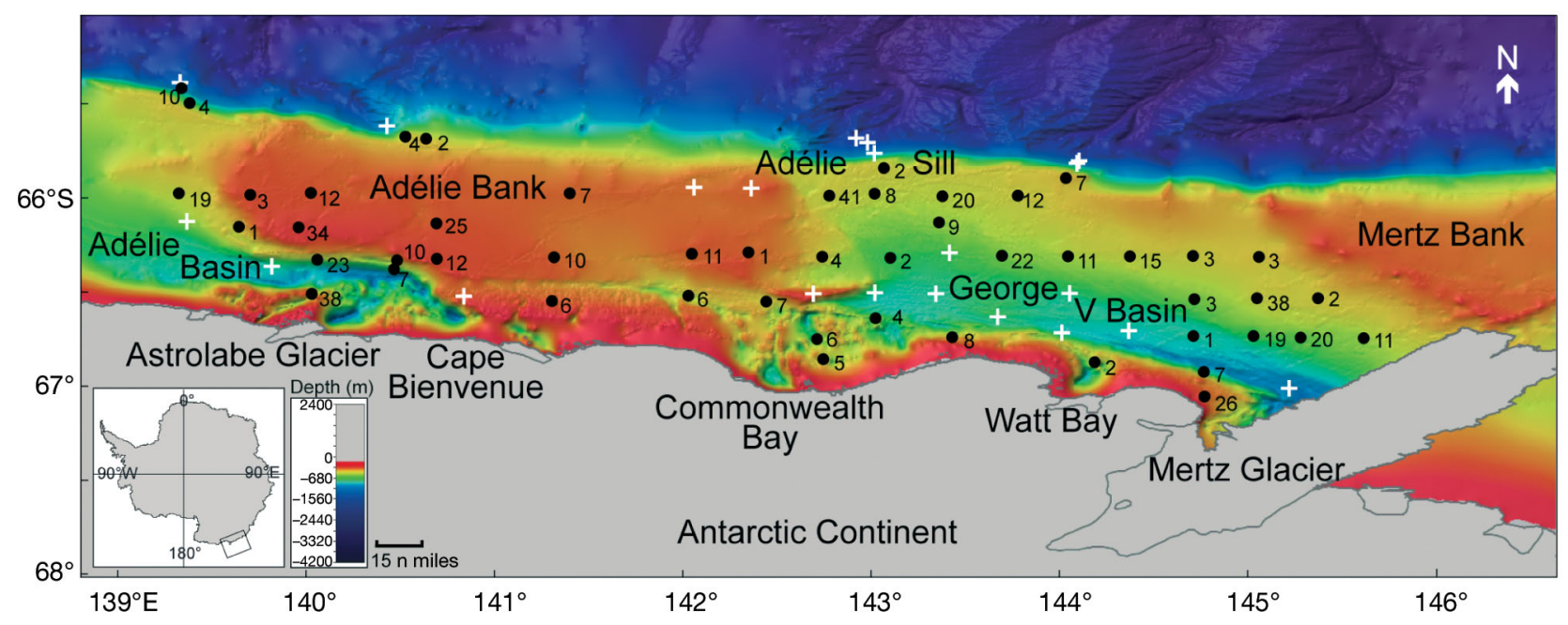

Fig. 1. Bathymetry of the Collaborative East Antarctic Marine Census survey area with the sampling stations. The inset at the left bottom corner shows the study area at the Antarctic scale. Black dots are stations with Anthometrina adriani; numbers represent the abundance of $A$. adriani per station; white crosses are the stations without any A. adriani; names are geographical feature names from Beaman et al. (2011) 
L. G. Hemery unpubl. results). Specimens were collected using a beam trawl $2.68 \mathrm{~m}$ in width, approximately 1.0 to $1.2 \mathrm{~m}$ in net height (depending on attachment point) and fitted with a $10 \times 10 \mathrm{~mm}$ mesh cod-end liner. All specimens collected were kept and immediately preserved in $80 \%$ ethanol. A total of 510 specimens of $A$. adriani were collected from 50 of the 87 stations (Fig. 1). Distances between adjacent stations were calculated in ArcGIS v. 9.2 by using the Hawth's analysis tools (Beyer 2004). The minimal and maximal distances between 2 adjacent stations are 1.7 and $30 \mathrm{~km}$, respectively, and the mean is $12.6 \mathrm{~km}$. The average time on the seabed for all trawls during the survey was $17 \mathrm{~min}$ (Eléaume et al. 2011b), with an average area covered of $1000 \mathrm{~m}^{2}$. However, the average length of a trawling event in which comatulids were collected was $738 \mathrm{~m}$.

\section{Abiotic or physical parameters}

Two different categories of abiotic parameters were used (Fig. 2): parameters likely to be subject to daily or seasonal variability (temperature, salinity, current magnitude, general current direction and sea-ice concentration) and parameters with longterm stability (bathymetry, slope, rugosity and seabed sediments). Parameters with short-term variability are taken from an oceanographic model, whereas parameters with long-term stability are derived from in situ measurements.
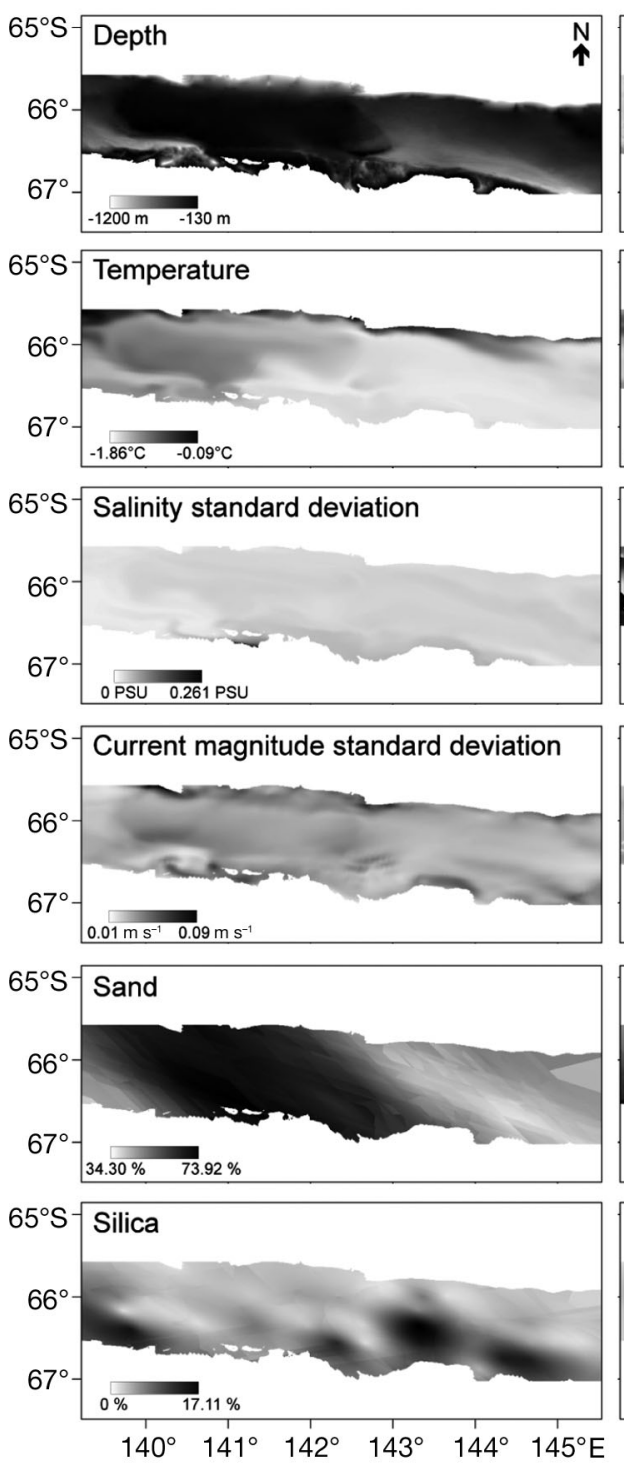
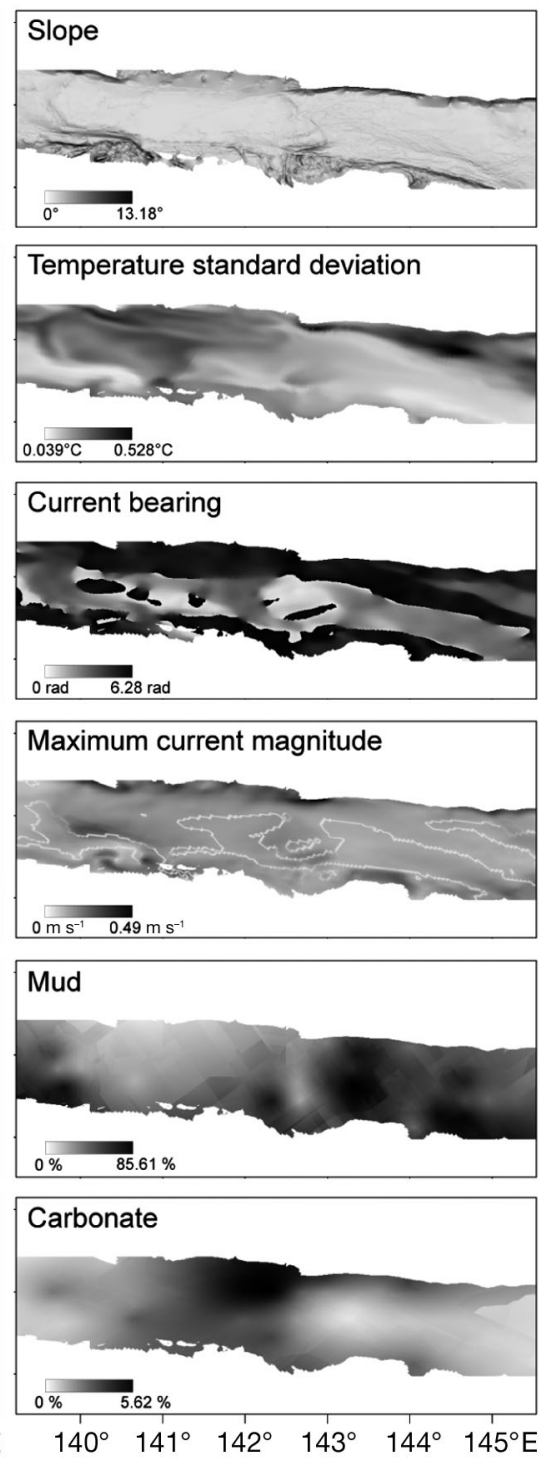
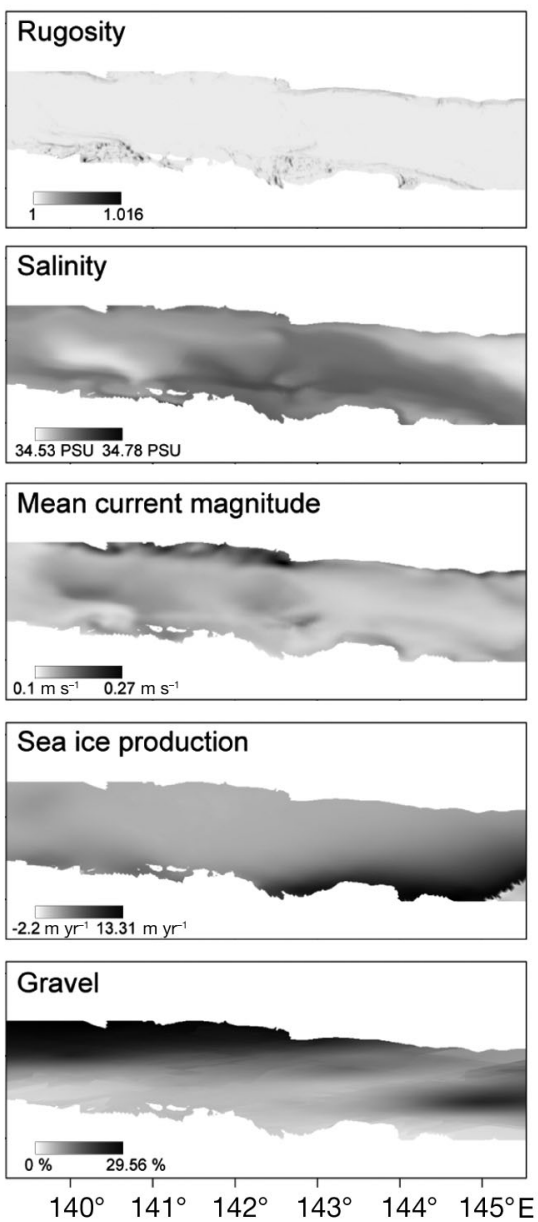

Fig. 2. The 17 different abiotic parameters used in the analyses. Shading ranges from light (low values) to dark (high values) 


\section{Physical oceanography}

Physical oceanographic parameters near the seabed (temperature, salinity, mean current magnitude, standard deviations of these 3 parameters, maximum current magnitude and general current direction) are taken from a climatologically forced ocean circulation model. The model was run for a total of $23 \mathrm{yr}$. A spinup phase of $20 \mathrm{yr}$ was required for the model to reach quasi-equilibrium. The mean and SD were calculated by using 6-hourly model data for the last $3 \mathrm{yr}$. Sea ice growth rate was calculated directly from special sensor microwave imager (SSM/I) observations (Tamura et al. 2008). The model is based on the Rutgers/University of California Los Angeles Regional Ocean Model System (ROMS; Shchepetkin \& McWilliams 2005) and is identical to the one described by B. K. Galton-Fenzi et al. (unpubl.). The model used here, initially developed for regional modelling studies of the Amery Ice Shelf/Ocean system and has been used in circum-Antarctic modelling studies, is able to simulate ice/ocean interactions at a high level of realism (Galton-Fenzi 2009, 2010). For the region of this study, the model is able to reproduce the circulation patterns and water mass properties when compared with oceanographic measurements taken in the vicinity of the George $\mathrm{V}$ and Adélie basins (A. Meijers pers. comm.).

The model domain extends from $135.77^{\circ} \mathrm{E}$ to $158.08^{\circ} \mathrm{E}$ and from $69.417^{\circ} \mathrm{S}$ to $62.724^{\circ} \mathrm{S}$. The southern boundary of the model is a closed, solid, free slip wall and the eastern and western boundaries are partially open. The horizontal grid resolution is between $2.16 \mathrm{~km}$ near the southern boundary to $2.88 \mathrm{~km}$ near the northern boundary. There are 31 vertical levels that are concentrated towards the top and bottom of the model domain. The parameters used here were taken from the lowest vertical level in the model that lies immediately adjacent to the seabed. The choice of mixing and advection schemes follows the choices that were successfully used by Dinniman et al. (2003, 2007) for studies of the shelf seas near the Ross Ice Shelf. The melting and freezing formulation uses the full 3-equation formulation and dynamics frazil ice model used in the studies of Galton-Fenzi (2009, 2010). Lateral boundary fields (potential temperature, salinity and currents) on the open boundaries are relaxed to monthly climatologies from ECCO2 (Menemenlis et al. 2008, Wunsch et al. 2009).

Ten primary tidal constituents were added as a free-surface forcing. The tidal amplitudes and phase are calculated with a nonstandard ROMS subroutine, based on tidal information from the Proudman
Oceanographic Laboratory (Murray 1964) and modified to be included within ROMS, yielding a standard tidal prediction. The bathymetry and the ice-draft information come from a version of R-TOPO (Timmermann et al. 2010) that was modified to include the high-resolution bathymetric data (outlined below, Beaman et al. 2011) and knowledge of the glacial ice drafts in the region (B. Legresy pers. comm.). The open ocean surface fluxes are modified by an imposed climatological sea-ice cover that includes polynyas, derived from SSM/I observations (Tamura et al. 2008). During summer, the Tamura et al. (2008) data are supplemented with open-water heat and salt fluxes by using the monthly climatologies from the NCEP-2 (Kanamitsu et al. 2002).

\section{Bathymetry and seabed sediments}

A bathymetry model based on multibeam swath sonar and single beam bathymetry data was produced at about $250 \mathrm{~m}$ resolution for the study area (Beaman et al. 2011). A raster map of the slope gradient was generated from this bathymetry model by using ESRI ArcGIS 9.2 Spatial Analysis Tools and a raster map of the rugosity was generated by using Benthic Terrain Modeler tools. Sediment grabs provided substratum composition data, such as the percentage of gravel, mud, sand, biogenic carbonate and biogenic silica at sample sites (Beaman \& O'Brien 2009). These data are used as a broad-scale representation of the seafloor substratum.

\section{Gridding technique}

Point data for abiotic parameters were interpolated by using ordinary kriging as implemented in ArcGIS v. 9.2 into a $0.005^{\circ}$ grid. All the maps were thus resampled to a $\sim 0.007^{\circ}$ grid corresponding to the mean trawling distance to sample Anthometrina adriani. A raster map was created for each abiotic parameter with ArcGIS tools (Fig. 2). Raster maps were limited to the shelf area and to a depth ranging from 130 to $1200 \mathrm{~m}$. The geographical extent of the maps was reduced to that of the smallest raster maps, which are the sediment distribution maps. The distribution of abiotic parameters assessed from histograms were generally non-normal; however, data were not normalized because the analyses used in this study are robust enough to deal with distribution that depart from normality (Hirzel et al. 2001, Basille et al. 2008). 


\section{Statistical tools to study the ecological niche}

Following the methods of several authors (e.g. Hirzel et al. 2002, Brotons et al. 2004, Basille et al. 2008) presence-only data were used in this study because retention and preservation of specimens were not consistent across all sampling sites. A set of multidimensional tools, ecological-niche factor analysis (ENFA; Hirzel et al. 2002) and Mahalanobis distances factor analysis (MADIFA, Calenge et al. 2008), is used here to explore the ecological niche (sensu Hutchinson 1957) of Anthometrina adriani. These techniques are based on factor analyses and are able to deal with parameters showing a non-normal distribution of their values (Basille et al. 2008). Each environmental variable defines a dimension in a hypervolume, which is the ecological space. The niche is described by the distribution of the species within the hypervolume, with each station weighted according to the number of occurrences (Basille et al. 2008). The ENFA analyses the data from the point of view of the environment, i.e. what is available for the species, whereas the MADIFA focuses on the habitat; i.e. what is used by the species. The 2 methods allow the prediction of the potential habitat for the species and the building of environmental suitability maps (ESM; Basille 2008).
These methods describe the 'available habitat', which is the quantity of any environmental variable accessible to the organisms, the 'used habitat', which is the quantity of any environmental variable used by the organisms and should be more restricted than the available habitat, and 'the optimal habitat', which should be the most suitable area for the organisms and thus even more restricted. The first axis ( $x$-axis on Fig. 3B,C) of the ENFA analysis represents 'marginality' of the habitat, which is the difference between the available habitat and the used habitat. It measures the eccentricity of the niche relative to the distribution of the available points in the ecological space. The following axes ( $y$-axis on Fig. 3B,C and other axes not shown) represent the 'specialization' of habitat and are axes on which the ratio of the variance of the available habitat to the used habitat is the highest. Specialization measures the narrowness of the niche.

These 2 analyses have been developed and applied to terrestrial animals, such as great mammals (e.g. Hirzel et al. 2002, Basille et al. 2008, Calenge \& Basille 2008) and birds (e.g. Hirzel et al. 2004, Olivier \& Wotherspoon 2006, Titeux et al. 2007). The ENFA has been recently applied to studies on marine animals such as cetaceans (e.g. MacLeod et al. 2008, Oviedo \& Solis 2008, Praca \& Gannier 2008), marine

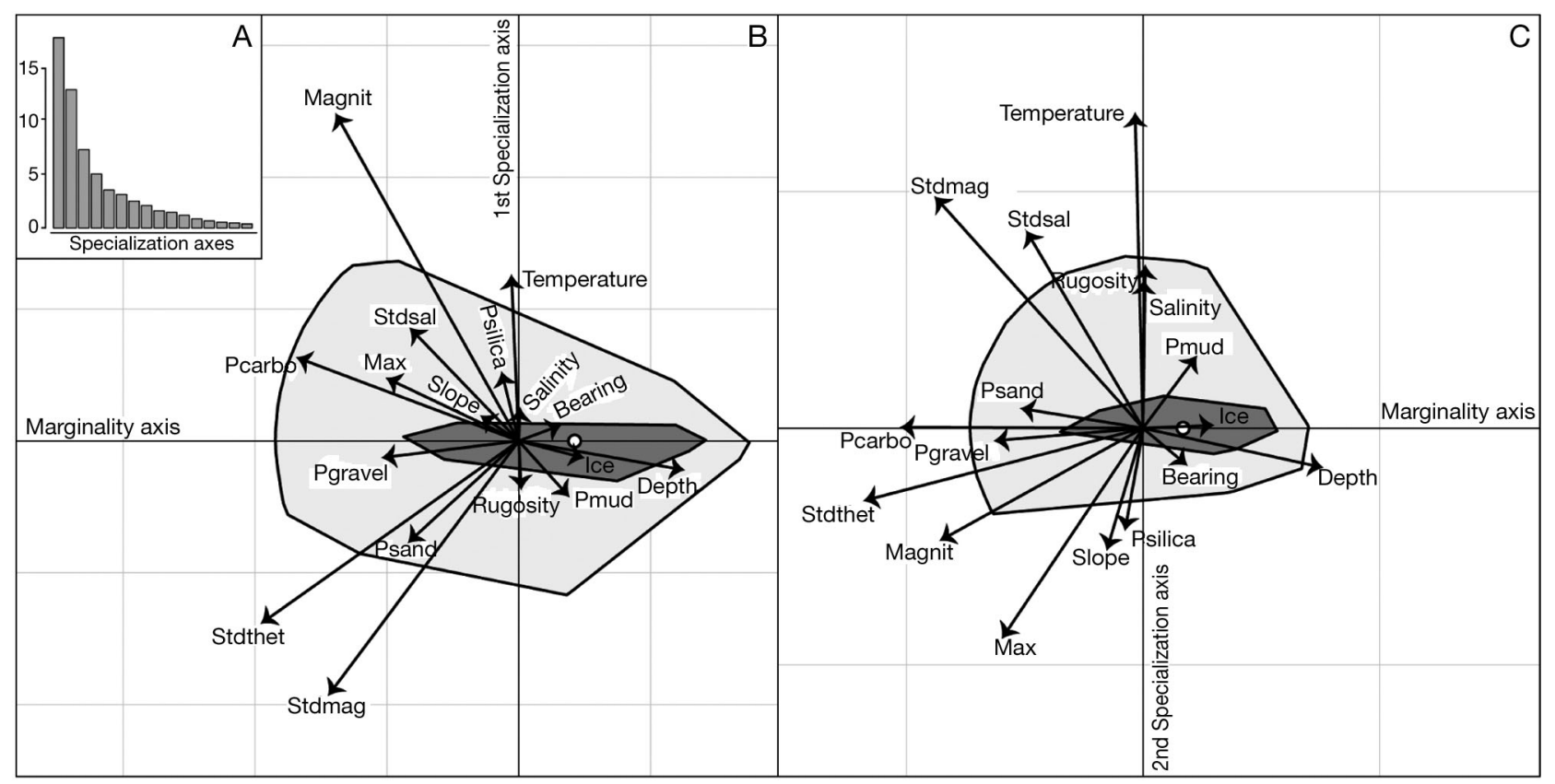

Fig. 3. Anthometrina adriani. (A) Eigenvalues of the ecological-niche factor analysis (ENFA): the $x$-axis is each axis of specialization and the $y$-axis is the eigenvalue. (B) Graphical representation of the results of the ENFA on the marginality ( $x$-axis) and the first axis of specialization ( $y$-axis); the light grey area is the available habitat and dark grey area is the used habitat; the white circle is the centroid of the used habitat; variable names are provided in Table 1. (C) Graphical representation of the results of the ENFA on the marginality ( $x$-axis) and the second axis of specialization ( $y$-axis) 
birds (e.g. Skov et al. 2008) and deep-sea corals (e.g. Davies et al. 2008, Tittensor et al. 2009), but never on vagile or quasi-sessile benthic organisms like Anthometrina adriani.

The ENFA and MADIFA multivariate analyses were performed using the functions 'enfa' and 'madifa' of the package adehabitat (Calenge 2006) available in the open-source software R (R Development Core Team 2009). The significance of both the marginality and the specialization axes of the ENFA were assessed with a Monte Carlo test as implemented in the 'niche.test' function in the package adehabitat with 999 iterations.

\section{RESULTS}

\section{ENFA: assessing the ecological niche of Anthometrina adriani}

The histogram of the eigenvalues (Fig. 3A) indicates that the 2 first axes account for most of the variance of the specialization ( 29 and $21 \%$, respectively). Three axes (marginality and the 2 first axes of specialization) account for most of the variance and are used in subsequent analysis. The marginality is 0.718. The optimal habitat for Anthometrina adriani is therefore different from the mean of available conditions. The eigenvalues of the 2 first axes of specialization are 17.74 and 12.91, respectively, which means that the variance of the available habitat is more than 17 times the variance of the used habitat in the first dimension and more than 12 times in the second dimension of the ecological space. The ecological niche is thus significantly narrower than the available habitat. The Monte Carlo test is highly significant $(p=0.001)$ for marginality and the axes of specialization.

The temperature SD, the carbonate, the current magnitude $\mathrm{SD}$ and the mean current magnitude correlate with the marginality axis at 49,42, 36 and $35 \%$, respectively (Table 1 , Fig. $3 \mathrm{~B}, \mathrm{C}$ ). The mean current magnitude highly correlates with the first specialization axis $(63 \%$, Table 1, Fig. 3B). Current magnitude $\mathrm{SD}$, temperature $\mathrm{SD}$ and temperature also correlate with this axis but to a lesser extent showing 49, 35 and $31 \%$, respectively (Table 1, Fig. 3B). The temperature correlates with the second specialization axis (55\%, Table 1, Fig. 3C). Current magnitude $\mathrm{SD}$, maximum current magnitude and salinity SD also correlate with this axis but to a lesser extent $(40,36$ and $34 \%$, respectively, Table 1 , Fig. 3C).
Table 1. Correlations (\%) between variables and axes for the ENFA (marginality and 1st and 2nd axes of specialization) and the MADIFA (1st and 2nd axes). Stdthet: temperature SD; stdsal: salinity SD; Psand: percent of sand; Pgravel: percent of gravel; Pcarbo: percent of biogenic carbonate; Pmud: percent of mud; Psilica: percent of biogenic silica; bearing: current bearing; magnit: current magnitude; stdmag: magnitude $\mathrm{SD}_{\text {; }}$ max: maximum current magnitude; ice: sea ice production. Values in bold text are important variables for each axis; values are rounded to the nearest integer. ' + ' represents positive part of the axes and '-' negative part of the axes

\begin{tabular}{|c|c|c|c|c|c|}
\hline \multirow[t]{2}{*}{ Variable } & \multicolumn{3}{|c|}{$\longrightarrow$ ENFA } & \multicolumn{2}{|c|}{ - MADIFA - } \\
\hline & Marginality & 1st axis & 2nd axis & 1st axis & 2nd axis \\
\hline Depth & +31 & -5 & -7 & -49 & -11 \\
\hline Slope & -6 & +4 & -20 & +18 & +21 \\
\hline Rugosity & 0 & -8 & +28 & -6 & +30 \\
\hline Tempera & ture -1 & +31 & +55 & +10 & +32 \\
\hline Stdthet & -49 & -35 & -13 & -14 & -17 \\
\hline Salinity & 0 & +5 & +25 & +12 & +42 \\
\hline Stdsal & -20 & +21 & +34 & -12 & +31 \\
\hline Psand & -20 & -19 & +3 & -11 & +17 \\
\hline Pgravel & -25 & -3 & -2 & +28 & +4 \\
\hline Pcarbo & -42 & +16 & 0 & +43 & +11 \\
\hline Pmud & +9 & -10 & +12 & -11 & -2 \\
\hline Psilica & -3 & +12 & -17 & -2 & 0 \\
\hline Bearing & +7 & +3 & -6 & +13 & -5 \\
\hline Magnit & -35 & +63 & -19 & +61 & +5 \\
\hline Stdmag & -36 & -49 & +40 & +24 & -9 \\
\hline Max & -24 & +12 & -36 & +43 & +5 \\
\hline Ice & +11 & -3 & 0 & -8 & -4 \\
\hline
\end{tabular}

\section{MADIFA: exploration of habitat selection by Anthometrina adriani}

The histogram of eigenvalues from the MADIFA (Fig. 4A) indicates that the 2 first axes account for most of the variance $(26 \%$ and $22 \%$, respectively, of the mean of the squared Mahalanobis distances). The following axes explain considerably less (each were $<13 \%$ ). The first and second axes were retained to further explore the results of the MADIFA by using a biplot (Fig. 4B,C).

Mean current magnitude, depth, maximum current magnitude and carbonate correlate with the first axis of the MADIFA at $61,49,43$ and $43 \%$, respectively (Fig. 4B, Table 1). Positive scores on this axis correspond to deep areas with carbonate and gravel but no mud in the sediment and with strong current velocity, whereas negative scores correspond to shallow areas with mud and sand in the sediment. The second axis of the MADIFA principally correlates with salinity $(42 \%)$, temperature $(32 \%)$, salinity SD $(31 \%)$ and rugosity $(30 \%)$. Positive scores on this axis correspond to relatively warm areas with rough high slope and salty waters. Negative scores on the second axis describe cold and moderately shallow waters with flat 


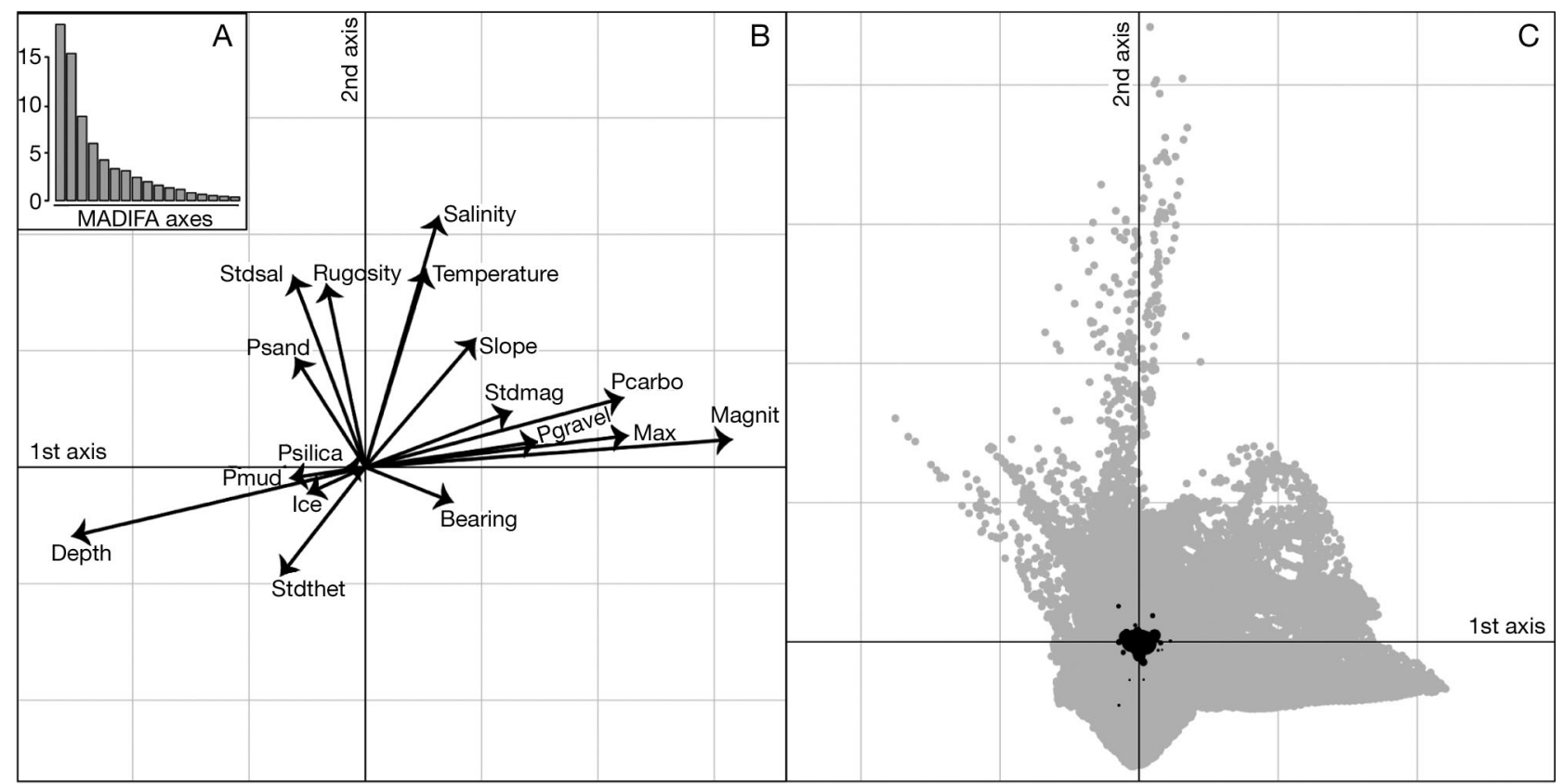

Fig. 4. Anthometrina adriani. (A) Eigenvalues of the Mahalanobis distances factor analysis (MADIFA): the $x$-axis is each axis of specialization and the $y$-axis is the eigenvalue value. (B) Graphical representation of the correlation between parameters on the MADIFA; $x$-axis and $y$-axis are, respectively, the first and the second axes of the MADIFA; variable names are provided in Table 1. (C) Factorial map showing the results of the MADIFA; $x$-axis and $y$-axis are, respectively, the first and the second axes of the MADIFA. Grey dots represent the available habitat whereas black dots represent the used habitat; their size is proportional to the number of specimens per station

and smooth slope areas. On the factorial map of the ecological space (Fig. 4C), the black dots (used habitats) are significantly offset on the first and second axis from the centre of the grey area and occupy part of the lower left sector of the available habitat.

\section{ESM: mapping of the optimal regions for Anthometrina adriani}

The optimal regions for this species were established using an ESM. The ESM was computed by using the 2 first axes of the MADIFA because they account for a large part of the variance (Fig. 5A,B). The optimality limits, -0.25 to 0.25 of Mahalanobis distances, were chosen to include most of the used points displayed on Fig. 4C. The resulting optimal region (Fig. 5C) corresponds to the intersection of optimal areas described by axes 1 and 2 of the MADIFA. Geomorphic features found in these optimal areas are the eastern sides of the George V Basin and the Adélie Basin, the southern part of the Adélie Bank but with some gaps and several coastal areas that are to the east of the Astrolabe Glacier, around Cape Bienvenue, Commonwealth Bay and Watt Bay.

\section{DISCUSSION}

\section{Suitable habitat for Anthometrina adriani}

The ecological niche (sensu Hutchinson 1957) of Anthometrina adriani is very different from the available habitat. It is principally defined by stable environmental conditions reflected by limited tolerance to environmental conditions outside the range found in their optimal habitat. Environments principally inhabited by A. adriani show low to moderate current velocity and limited variability in a number of parameters including temperature and salinity. The importance of substratum is difficult to assess here because $A$. adriani has been observed perching on other organisms rather than sitting directly on the sediment. A. adriani shows a reduced genetic diversity within its whole distribution area (M. Eléaume \& L. G. Hemery unpubl. results) and high dispersal capacities. This suggests high population connectivity. In addition, $A$. adriani is circumpolar in distribution (see Eléaume 2006 for a review) indicating that the optimal habitat is also circumpolar in distribution even if it is patchy.

Anthometrina adriani is a conspicuous element of the benthic assemblages, sitting on top of crests or 

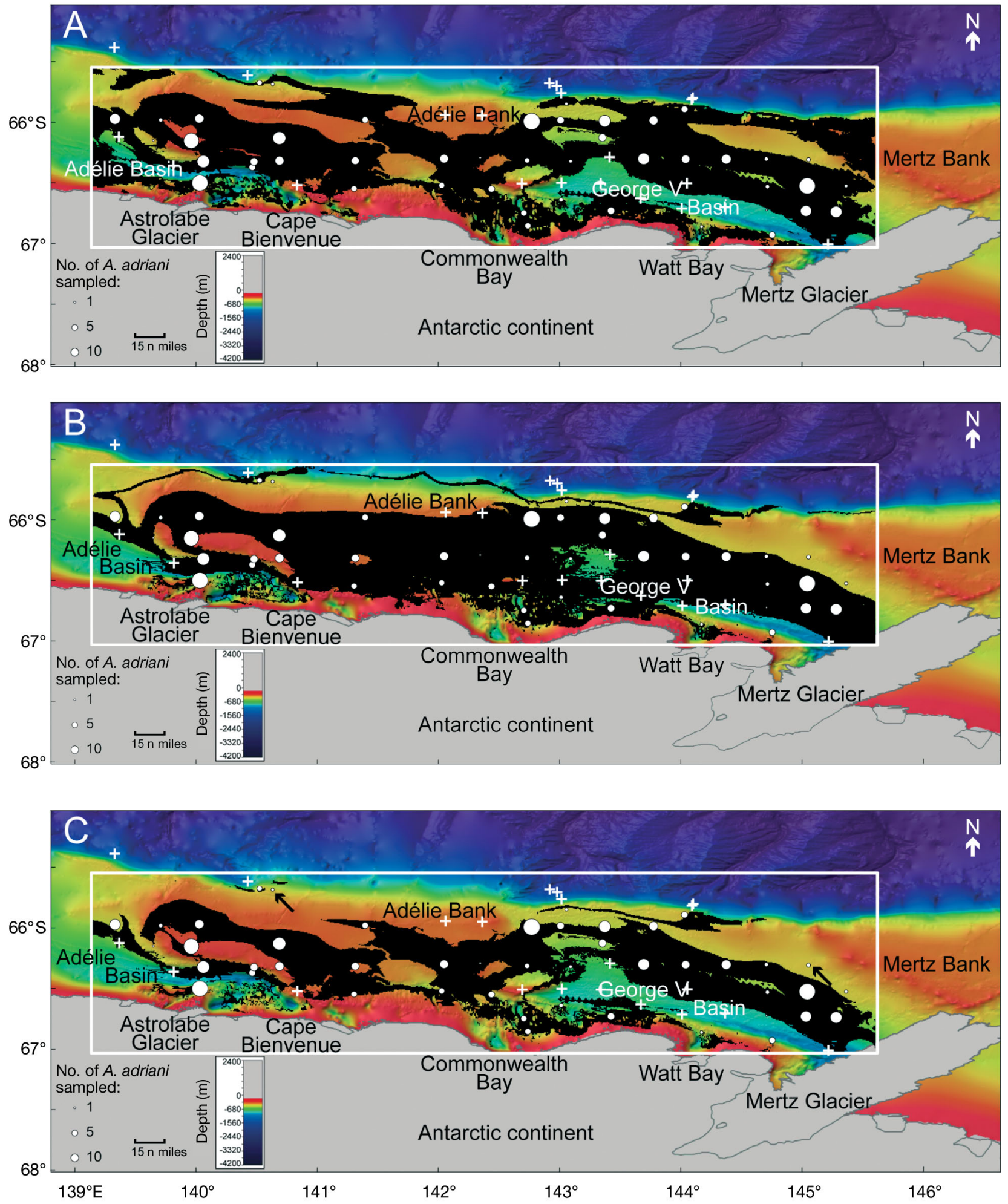

Fig. 5. Anthometrina adriani. (A) Environmental suitability map (ESM) computed on the first axis of the MADIFA. (B) ESM computed on the second axis of the MADIFA. (C) Final ESM optimising results from both axes. The studied region is contained with the white frame; dots are sampling stations during the CEAMARC Survey on the RV 'Aurora Australis' (dot size is proportional to sampled specimen number); black areas are optimum areas; black arrows point to stations outside the optimal habitat; white crosses are the stations without $A$. adriani; the background is the bathymetry 
perching on other organisms. This suggests that it selects for environmental conditions with suitable current velocity that permit food gathering. These observations suggest that $A$. adriani is a rheophilic suspension feeder comparable to other species that have a similar feeding posture (see Meyer 1997 for a review). Our results are congruent with this assumption and indicate that $A$. adriani selects for low to moderate current velocity from 0 to $15 \mathrm{~cm} \mathrm{~s}^{-1}$. These values fall in the measured current velocity range for similar species (Meyer 1997).

The Adélie Basin and George V Basin are completely excluded from the optimal regions for Anthometrina adriani, whereas the eastern sides of both the George V Basin and the Adélie Basin, the southern part of the Adélie Bank and inner-shelf areas between the Astrolabe and Mertz Glaciers are included. These optimal regions have low gravel content, with a composition dominated by sand with moderate mud content, and have a low proportion of biogenic carbonate and silica. Overall, there is a low level of total organic carbon in the studied area, and the optimal regions for $A$. adriani are among the poorest. The benthic assemblages observed in these regions are multilayered and mostly undisturbed, though with traces of relict scouring on the banks due to icebergs with a deep keel (Post et al. 2011).

The Mertz Glacier tongue has now broken off and passed through the Dumont D'Urville Sea. Another giant iceberg, the $\mathrm{B} 9 \mathrm{~B}$, is now slowly drifting away along the coast of George V Land. These icebergs may have affected the benthic communities over the eastern side of the George V Basin during the summer of 2010-2011 along its drifting trajectory (E. Sultan pers. comm.). In addition, the position and effect of the Mertz polynyas may also change over time, and the temperature and salinity of the water masses in this sector may significantly change. Given that Anthometrina adriani seems to survive only under a narrow range of environmental biotic and abiotic conditions, these changes may heavily affect its distribution in the region.

\section{Application of the ENFA and MADIFA on a benthic invertebrate}

The ENFA and the MADIFA statistical tools use presence-only data (Hirzel et al. 2002, Brotons et al. 2004, Basille et al. 2008). This kind of analysis is particularly well suited to marine organisms sampled on a regular grid of stations as was the case during the CEAMARC survey. However, because stations were relatively widely separated (mean of $12.6 \mathrm{~km}$ between 2 adjacent stations), comatulids may exist at many locations where they were not sampled. The ENFA, and then MADIFA, can offset this bias and be suitable and efficient with data for which absences are unreliable or unknown (Hirzel et al. 2001). Furthermore, it is not necessary to know the limiting factors of the species but just to have an idea of which parameters could influence the species establishment and maintenance. These analyses can highlight which of the environmental variables that we have used are of interest for the species (Calenge \& Basille 2008). As little is known about the environmental preferences of comatulid crinoids in Antarctica, we decided to use all environmental parameters available in the study area, except oxygen, which is closely correlated to temperature. The analyses revealed that some of the parameters we used are more relevant than others, in particular current magnitude, depth and bottom temperature.

Temperature and salinity are potentially sensitive to climate change processes and are being included in regional models used for predicting likely trajectories of change in the Southern Ocean under differing climate change scenarios (Convey et al. 2009, Turner et al. 2009). Currents are caused by tides, bottom topography, ocean properties and atmospheric forcing. Climate change processes can influence ocean currents and, therefore, sedimentation rates and thus influence survival of suspension feeders. The Antarctic Peninsula, Amundsen Sea and Bellingshausen Sea are the Antarctic regions currently undergoing the most rapid environmental changes (Griffiths 2010). For the moment, East Antarctic is not affected but this region could suffer changes in the next decades. As Convey et al. (2009, p. 3) stated, 'understanding the impact of past, current and predicted environmental change on biodiversity and the consequences for Antarctic ecosystem adaptation and function must be a primary goal of research today.' Our analysis illustrates how ecological niche models could be broadened to explore the potential impacts of climate change scenarios on the distribution of benthic species such as $A n$ thometrina adriani. This kind of study could also provide important information in support of area management, such as determining the appropriate size and location for marine protected areas. Optimal habitats are known to house source populations for many species (Dias 1996). In the case of $A$. adriani, at least 2 stations with few $A$. adriani specimens are outside the optimal regions described on both axes of the MADIFA (Fig. 5C, indicated by arrows) and these specimens may represent sink populations sustained by populations in optimal regions. 
Acknowledgements. We thank the ANTFLOCKS project funded by the French national research agency ('ANR'; USAR no. 07-BLAN-0213-01). Funding parties also include the Département des Milieux et Peuplements Aquatiques at the Muséum national d'Histoire naturelle in Paris, the ATM 'Biodiversité actuelle et fossile; crises, stress, restaurations et panchronisme: le message systématique', the French polar institute IPEV and the SCAR. The RV 'Aurora Australis' V3 voyage 2007-2008 was part of the Collaborative East Antarctic Marine Census (CEAMARC) program, International Polar Year (IPY) project 53 of the Census of Antarctic Marine Life (CAML). We also thank P. Koubbi, A. Goarant and F. Penot for their help with the CEAMARC data. L.G.H. also acknowledges C. Calenge for guiding her first steps with 'adehabitat' and G. Vieilledent and A. Hemery for the choice of the ENFA and MADIFA among the large panel of available analyses. A.L.P. publishes with the permission of the Chief Executive Officer, Geoscience Australia. R.J.B. acknowledges a Queensland Smart Futures Fellowship for salary support. Support from the Australian Government's Cooperative Research Centre (CRC) program, through the Antarctic Climate and Ecosystem CRC, is also acknowledged. We also thank the 4 anonymous referees for constructively reviewing the manuscript.

\section{LITERATURE CITED}

Basille M (2008) Habitat selection by lynx (Lynx lynx) in a human-dominated landscape. From theory to application. PhD dissertation, Université Claude Bernard-Lyon 1

Basille M, Calenge C, Marboutin E, Andersen R, Gaillard JM (2008) Assessing habitat selection using multivariate statistics: some refinements of the ecological-niche factor analysis. Ecol Model 211:233-240

Beaman RJ, O'Brien PE (2009) Collaborative East Antarctic marine census (CEAMARC): Post-survey report, RSV Aurora Australis Voyage 3, December 2007-January 2008. Geosci Aust Rec 2009/05

Beaman RJ, O'Brien PE, Post AL, De Santis L (2011) A new high-resolution bathymetry model for the Terre Adélie and the George V continental margin, East Antarctica. Antarct Sci 23:95-103

Beyer HL (2004) Hawth's analysis tools for ArcGIS. www. spatialecology.com/htools

> Bindoff NL, Rosenberg MA, Warner MJ (2000) On the circulation and water masses over the Antarctic continental slope and rise between 80 and $150^{\circ}$ E. Deep-Sea Res II 47:2299-2326

> Brotons L, Thuiller W, Araujo MB, Hirzel AH (2004) Presenceabsence versus presence-only modelling methods for predicting bird habitat suitability. Ecography 27:437-448

Bullivant JS (1959) Photography of the bottom fauna in the Ross Sea. NZ J Sci 2:485-497

Calenge C (2006) The package 'adehabitat' for the R software: a tool for the analysis of space and habitat use by animals. Ecol Model 197:516-519

Calenge C, Basille M (2008) A general framework for the statistical exploration of the ecological niche. J Theor Biol 252:674-685

> Calenge C, Darmon G, Basille M, Loison A, Jullien JM (2008) The factorial decomposition of the Mahalanobis distances in habitat selection studies. Ecology 89:555-566

Clarke A (1996) Benthic marine habitats in Antarctica. Antarct Res Ser 70:123-133
Convey P, Bindschadler R, di Prisco G, Fahrbach E and others, and the ACCE Consortium (2009) Antarctic climate change and the environment. Antarct Sci 21:541-563

> Davies AJ, Wisshak M, Orr JC, Roberts JM (2008) Predicting suitable habitat for the cold-water coral Lophelia pertusa (Scleractinia). Deep-Sea Res I 55:1048-1062

> Dias PC (1996) Sources and sinks in population biology. Trends Ecol Evol 11:326-330

> Dinniman MS, Klinck JM, Smith WO (2003) Cross-shelf exchange in a model of the Ross Sea circulation and biogeochemistry. Deep-Sea Res II 50:3103-3120

> Dinniman MS, Klinck JM, Smith WO (2007) Influence of sea ice cover and icebergs on circulation and water mass formation in a numerical circulation model of the Ross Sea, Antarctica. J Geophys Res 112:C1013, doi:10.1029/ 2006JC004036

> Dowdeswell JA, Bamber JL (2007) Keel depths of modem Antarctic icebergs and implications for sea-floor scouring in the geological record. Mar Geol 243:120-131

Eléaume M (2006) Approche morphométrique de la variabilité phénotypique: conséquences systématiques et évolutives. Application aux crinoïdes actuels (Crinoidea: Echinodermata). PhD dissertation, Muséum national d'Histoire naturelle, Paris

Eléaume M, Baumiller TK, Améziane N (2003) Developmental mode, egg size, larval size and some evolutionary considerations in comatulids (Crinoidea; Echinodermata). In: Féral JP, David B (eds) Echinoderm research 2001. Proc 6th Eur Conf, Banyuls-sur-mer, 3-7 Sep 2001. Swets \& Zeitlinger, Lisse, p 143-148

Eléaume M, Hess H, Messing CG (2011a) Nomenclatorial note: Anthometrina, new name for the genus Anthometra Clark, 1915 (Crinoidea, Comatulidina), preoccupied by Anthometra Boisduval, 1840 (Arthropoda, Lepidoptera). In: Seldon P (ed), Ausich WI (coordinating author) Treatise on invertebrate paleontology, part T (revised), Vol 3. University of Kansas Press, Lawrence, KS, p 224

Eléaume M, Beaman RJ, Griffiths HJ, Best B and others (2011b) Near bottom current direction inferred from comatulid crinoid feeding postures on the Terre Adélie and George V shelf, East Antarctica. Deep-Sea Res II 58: 163-169

Galton-Fenzi BK (2009) Modelling ice-shelf/ocean interaction. PhD dissertation, University of Tasmania and CSIRO

Galton-Fenzi BK (2010) Modelling the interaction between Antarctica and the Southern Ocean. In: Hollis AJ, Day KA (eds) Ocean science-extended abstracts of the fourth CAWCR Workshop, 9-11 Nov 2010, Hobart, Tasmania. Centre for Australian Weather and Climate Research (CAWCR) Tech Rep 33, p 33-37

Griffiths HJ (2010) Antarctic marine biodiversity - What do we know about the distribution of life in the Southern Ocean? PLoS ONE 5:e11683

Guisan A, Zimmermann NE (2000) Predictive habitat distribution models in ecology. Ecol Model 135:147-186

Gutt J (2006) Coexistence of macro-zoobenthic species on the Antarctic shelf: an attempt to link ecological theory and results. Deep-Sea Res II 53:1009-1028

> Hirzel AH, Helfer V, Metral F (2001) Assessing habitat-suitability models with a virtual species. Ecol Model 145: 111-121

Hirzel AH, Hausser J, Chessel D, Perrin N (2002) Ecologicalniche factor analysis: How to compute habitat-suitability maps without absence data? Ecology 83:2027-2036 
Hirzel AH, Posse B, Oggier PA, Crettenand Y, Glenz C, Arlettaz R (2004) Ecological requirements of reintroduced species and the implications for release policy: the case of the bearded vulture. J Appl Ecol 41:1103-1116

Holland ND (1991) Echinodermata Crinoidea. In: Giese AC, Pearse JS, Pearse VB (eds) Reproduction of marine invertebrates, Vol 6. Boxwood Press, Pacific Grove, CA, p 247-299

Hutchinson GE (1957) Concluding remarks. Cold Spring Harbour Symp Quant Biol 22:415-427

Kanamitsu M, Ebisuzaki W, Woollen J, Yang SK, Hnilo JJ, Fiorino M, Potter GL (2002) NCEP-DOE AMIP-II reanalysis (R-2). Bull Am Meteorol Soc 83:1631-1643

MacLeod CD, Mandleberg L, Schweder C, Bannon SM, Pierce GJ (2008) A comparison of approaches for modelling the occurrence of marine animals. Hydrobiologia 612:21-32

- Macurda DB, Meyer DL (1974) Feeding posture of modern stalked crinoids. Nature 247:394-396

> Massom RA, Hill KL, Lytle VI, Worby AP, Paget M, Allison I (2001) Effects of regional fast-ice and iceberg distributions on the behaviour of the Mertz Glacier polynya, East Antarctica. Ann Glaciol 33:391-398

McClintock JB, Pearse JS (1987) Reproductive biology of the common Antarctic crinoid Promachocrinus kerguelensis (Echinodermata, Crinoidea). Mar Biol 96:375-383

Menemenlis D, Campin JM, Heimbach P, Hill C and others (2008) ECCO2: High resolution global ocean and sea ice data synthesis. Mercator Ocean Q Newsl 31:13-21

> Meyer DL (1973) Feeding behavior and ecology of shallowwater unstalked crinoids (Echinodermata) in the Caribbean Sea. Mar Biol 22:105-129

Meyer DL (1997) Reef crinoids as current meters: feeding responses to variable flow. Proc 8th Int Coral Reef Symp, Panama City 2:1127-1130

Meyer DL, Macurda DB (1980) Ecology and distribution of the shallow water crinoids of Palau and Guam. Micronesia 16(1):59-99

Murray MT (1964) A general method for the analysis of hourly heights of the tide. Int Hydrogr Rev 41:91-101

> O'Donnell M, Hammond L, Hofmann G (2009) Predicted impact of ocean acidification on a marine invertebrate: elevated $\mathrm{CO}_{2}$ alters response to thermal stress in sea urchin larvae. Mar Biol 156:439-446

Olivier F, Wotherspoon SJ (2006) Modelling habitat selection using presence-only data: case study of a colonial hollow nesting bird, the snow petrel. Ecol Model 195: 187-204

Oviedo L, Solis M (2008) Underwater topography determines critical breeding habitat for humpback whales near Osa Peninsula, Costa Rica: implications for marine protected areas. Rev Biol Trop 56:591-602

Paine RT (1969) A note on trophic complexity and community stability. Am Nat 103:91-93

Post AL, Beaman RJ, O'Brien PE, Eléaume M, Riddle MJ (2011) Community structure and benthic habitats across the George V Shelf, East Antarctica: trends through

Editorial responsibility: James McClintock, Birmingham, Alabama, USA space and time. Deep-Sea Res II 58:105-118

Praca E, Gannier A (2008) Ecological niches of three teuthophageous odontocetes in the northwestern Mediterranean Sea. Ocean Sci 4:49-59

R Development Core Team (2009) R: a language and environment for statistical computing. R Foundation for Statistical Computing, Vienna. www.R-project.org

- Raguá-Gil JM, Gutt J, Clarke A, Arntz WE (2004) Antarctic shallow-water mega-epibenthos: shaped by circumpolar dispersion or local conditions? Mar Biol 144:829-839

Rintoul SR (1998) On the origin and influence of Adélie Land Bottom Water. In: Jacobs S, Weiss R (eds) Ocean, ice and atmosphere: interaction at the Antarctic continental margin. American Geophysical Union, Washington, DC, p 151-171

Shchepetkin AF, McWilliams JC (2005) The regional oceanic modeling system (ROMS): a split-explicit, freesurface, topography-following-coordinate oceanic model. Ocean Model 9:347-404

Skov H, Humphreys E, Garthe S, Geitner K and others (2008) Application of habitat suitability modelling to tracking data of marine animals as a means of analyzing their feeding habitats. Ecol Model 212:504-512

Smale DA, Barnes DKA (2008) Likely responses of the Antarctic benthos to climate-related changes in physical disturbance during the 21st century, based primarily on evidence from the West Antarctic Peninsula region. Ecography 31:289-305

Tamura T, Ohshima KI, Nihashi S (2008) Mapping of sea ice production for Antarctic coastal polynyas. Geophys Res Lett 35:L07606, doi:10.1029/2007GL032903

> Timmermann R, Le Brocq A, Deen T, Domack E and others (2010) A consistant data set of Antarctic ice sheet topography, cavity geometry and global bathymetry. Earth Syst Sci Data 2:261-273

- Titeux N, Dufrene M, Radoux J, Hirzel AH, Defourny P (2007) Fitness-related parameters improve presenceonly distribution modelling for conservation practice: the case of the red-backed shrike. Biol Conserv 138: 207-223

Tittensor DP, Baco AR, Brewin PE, Clark MR and others (2009) Predicting global habitat suitability for stony corals on seamounts. J Biogeogr 36:1111-1128

Turner J, Bindschadler R, Convey P, di Prisco G and others (2009) Antarctic climate change and the environment. Scientific Committee for Antarctic Research, Cambridge

> Underwood AJ, Fairweather PG (1989) Supply-side ecology and benthic marine assemblages. Trends Ecol Evol 4: $16-20$

> Wilson NG, Hunter RL, Lockhart SJ, Halanych KM (2007) Multiple lineages and absence of panmixia in the 'circumpolar' crinoid Promachocrinus kerguelensis from the Atlantic sector of Antarctica. Mar Biol 152:895-904

Wunsch C, Heimbach P, Ponte R, Fukumori I, ECCOGODAE consortium members (2009) The global general circulation of the ocean estimated by the ECCO consortium. Oceanography 22:88-103

Submitted: May 13, 2011; Accepted: July 29, 2011

Proofs received from author(s): November 1, 2011 